\title{
Phenolic Compounds Present Schinus terebinthifolius Raddi Influence the Lowering of Blood Pressure in Rats
}

\author{
Lorena de Lima Glória ${ }^{1}$, Mariana Barreto de Souza Arantes ${ }^{1}$, Silvia Menezes de Faria Pereira ${ }^{1}$, \\ Guilherme de Souza Vieira ${ }^{2}$, Camilla Xavier Martins ${ }^{2}$, Almir Ribeiro de Carvalho Junior ${ }^{3}$ (D), \\ Fernanda Antunes ${ }^{2}$, Raimundo Braz-Filho ${ }^{3}$, Ivo José Curcino Vieira ${ }^{3}$, Larissa Leandro da Cruz ${ }^{1}$, \\ Douglas Siqueira de Almeida Chaves ${ }^{4}$, Silvério de Paiva Freitas ${ }^{5}$ \\ and Daniela Barros de Oliveira ${ }^{1, *}$
}

1 Laboratório de Tecnologia de Alimentos, CCTA, Universidade Estadual do Norte Fluminense Darcy Ribeiro, Campos dos Goytacazes 28013-602, Brazil; lorena_limagloria@hotmail.com (L.d.L.G.); mariana.arant@yahoo.com.br (M.B.d.S.A.); silvia@uenf.br (S.M.d.F.P.); larissa.leandrocruz@gmail.com (L.L.d.C)

2 Laboratório de Clínica e Cirurgia Animal, CCTA, Universidade Estadual do Norte Fluminense Darcy Ribeiro, Campos dos Goytacazes 28013-602, Brazil; guilhermesv.medvet@gmail.com (G.d.S.V.); camilla.xm@gmail.com (C.X.M.); prfernandaantunes@yahoo.com.br (F.A.)

3 Laboratório de Ciências Químicas, CCT, Universidade Estadual do Norte Fluminense Darcy Ribeiro, Campos dos Goytacazes 28013-602, Brazil; almir@uenf.br (A.R.d.C.J.); braz@uenf.br (R.B.-F.); curcino@uenf.br (I.J.C.V.)

4 Laboratório de Química de Bioativos Naturais, Departamento de Ciências Farmacêuticas, Universidade Federal Rural do Rio de Janeiro, Seropédica 23897-000, Brazil; chavesdsa@yahoo.com.br

5 Laboratório de Fitotecnia, Universidade Estadual do Norte Fluminense Darcy Ribeiro, Campos dos Goytacazes 28013-602, Brazil; silverio@uenf.br

* Correspondence: dbarrosoliveira@uenf.br; Tel.: +55-22-2748-6517

Received: 28 September 2017; Accepted: 18 October 2017; Published: 23 October 2017

\begin{abstract}
This study identified two phenolic compounds in Schinus terebinthifolius Raddi fruits: naringenin (first report in this species) and gallic acid. Their structures were elucidated by nuclear magnetic resonance (NMR) data $\left({ }^{1} \mathrm{H}-,{ }^{13} \mathrm{C}-\mathrm{NMR}\right)$ and a high-performance liquid chromatography (HPLC) technique. A high content of phenolics (659.21 mg of gallic acid equivalents/g of sample-Folin-Ciocalteau method) and total flavonoids (140.69 $\mathrm{mg}$ of rutin equivalents/g of sample-aluminum chloride method) were quantified in S. terebinthifolius, as well as high antioxidant activity (77.47\%-2,2-diphenyl-1-picrylhydrazyl, DPPH method). The antihypertensive activity related to its phenolic content was investigated. After intravenous infusion in Wistar rats, these phenolics significantly reduced $(p<0.05)$ the systolic, median, and diastolic arterial pressures of individuals. The rotarod test was performed to determine the mechanism of action of the sample vasorelaxant effect. It was found that its action exceeded that of the positive control used (diazepam). This confirmed the vasodilatory activity exerted by $S$. terebinthifolius fruits is related to the phenolic compounds present in the plant, which are potent antioxidants and inhibit oxidative stress, mainly in the central nervous system.
\end{abstract}

Keywords: Schinus terebinthifolius Raddi; Anacardiaceae; naringenin; gallic acid; blood pressure; rotarod 


\section{Introduction}

The World Health Organization (WHO) reported that about three-quarters of the world's population make use of medicinal plants to improve health [1]. Medicinal plants can be considered one of the oldest forms of health care $[2,3]$.

Schinus terebinthifolius Raddi, Anacardiaceae, is a plant native to South America popularly known as Aroeira or Pink Pepper [4]. This species is one of 71 medicinal plants reported in the National Relation of Medicinal Plants (RENISUS), which are of interest to the Brazilian Unified Health System (SUS) [5]. This list was created to promote and acknowledge the popular use of medicinal plants with potential effect on primary health care [5].

The discovery of biological activities attributed to phenolic compounds has been widely reported in several studies and has led the scientific community to carry out epidemiological studies on the likely associations between phenolic compounds and reduced risk for various diseases [6,7]. Natural compounds are responsible for the protective effect of cells against oxidative damage caused by Reactive Oxygen Species (ROS) [8]. Excess ROS in the body can cause a number of complications [7,8]. Antioxidants, which are responsible for neutralizing the effects of ROS and the scavenging of free radicals, may favor cardiovascular parameters in individuals $[9,10]$.

Considering the importance of phenolic compounds and aiming to identify new natural sources with high biological potential, the total phenolics and flavonoids were quantified and the antioxidant activity and cardiovascular activity of the phenolic compounds in Schinus terebinthifolius Raddi fruits was determined. The present work is the first report on flavonoid naringenin and the activities attributed to it in this species.

\section{Results and Discussion}

\subsection{Identification and Structure Elucidation of the Major Compounds}

The methanolic extract of Schinus terebinthifolius was partitioned into aqueous and organic fractions. The organic fraction was subjected twice to Sephadex LH-20 column chromatography to produce the G5 fraction, whose chemical profile was analyzed by High Performance Liquid Chromatography with a Diode-Array Detector (HPLC-DAD) (Figure 1).

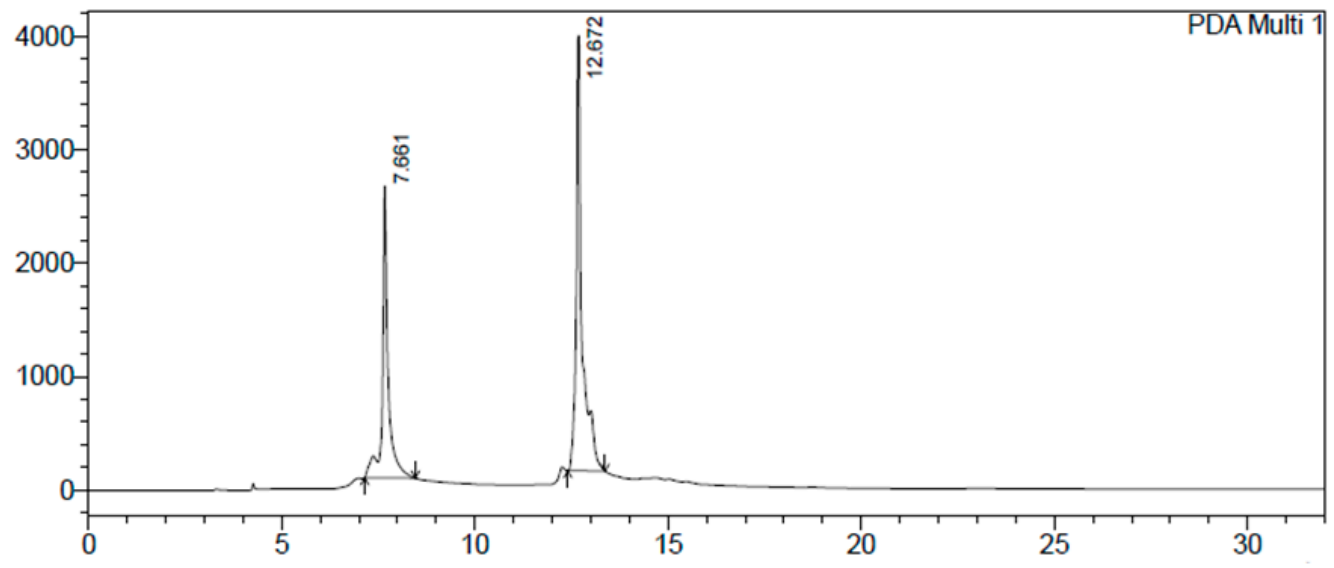

Figure 1. Chromatogram of the High Performance Liquid Chromatography with a Diode-Array Detector (HPLC-DAD) analysis of the investigated G5 fraction from Schinus terebinthifolius Raddi fruit extract $(4.0 \mathrm{mg} / \mathrm{mL})$ at wavelength of $254 \mathrm{~nm}$. Analytical conditions: stationary phase: RP-18 reverse-phase column (5 $\mathrm{m}, 250 \mathrm{~mm}, 4.5 \mathrm{~mm}$, Macherey-Nagel); temperature: $32{ }^{\circ} \mathrm{C}$; mobile phase: $\mathrm{A}=$ purified water adjusted to $\mathrm{pH} 3.2$ with phosphoric acid, $\mathrm{B}=$ acetonitrile; flow rate: $1.0 \mathrm{~mL} / \mathrm{min}$; detection: $254 \mathrm{~nm}$; injection volume: $20 \mu \mathrm{L}$; solvent composition during analysis: $0^{\prime}: 100 \% \mathrm{~A} ; 5^{\prime}: 70 \% \mathrm{~A}$; $10^{\prime}: 50 \%$ A; $15^{\prime}: 30 \%$ A; $20^{\prime}: 20 \%$ A; $25^{\prime}: 10 \%$ A; $30^{\prime}$ : $0 \%$ A; $32^{\prime}$ : stop. 
The chromatogram shows two major peaks at retention times 7.7 and $12.7 \mathrm{~min}$. Kanaze et al. (2004) validated a methodology for HPLC assay and identified naringenin at retention time $13.1 \mathrm{~min}$, while Song et al. (2012) developed a methodology to determine phenols in HPLC and found gallic acid at the retention time $7.71 \mathrm{~min}[11,12]$.

Although Kanaze et al. (2004) and Song et al. (2012) have identified compounds with retention time close to those demonstrated in the present study, the authors did not use the same method of analysis developed by us, so without NMR analysis, we cannot be sure about identity of the analytes [11,12].

Although Kanaze et al. (2004) and Song et al. (2012) identified compounds with retention time close to those demonstrated in the present study, the authors did not use the same method of analysis developed by us, so without NMR analysis, we cannot be sure about identity of the analytes [11,12].

The prevailing compounds present in the G5 fraction of S. terebinthifolius were identified, namely, a flavonoid and a phenolic acid: naringenin (1) and gallic acid (2) (Figure 2). The phenolic compounds were identified by NMR analysis (figures shown in Supplementary Material) sand comparing their ${ }^{1} \mathrm{H}-,{ }^{13} \mathrm{C}-\mathrm{NMR}$ spectral data with values in the literature $[13,14]$. Naringenin was reported for the first time in the fruits of this plant.

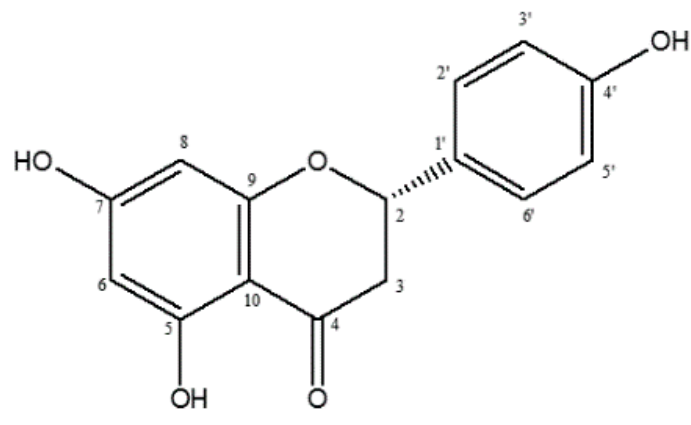

1<smiles>O=C(O)c1cc(O)c(O)c(O)c1</smiles>

2

Figure 2. Chemical structures of compounds 1 and 2.

Compound 1 was obtained as yellow powder. ${ }^{1} \mathrm{H}\left(\mathrm{DMSO}-d_{6}, 500 \mathrm{MHz}\right): \delta_{\mathrm{H}} 7.22\left(2 \mathrm{H}, \mathrm{d}, \mathrm{H}-2^{\prime}\right.$ and H-6 $), 6.70\left(2 \mathrm{H}, \mathrm{d}, \mathrm{H}-3^{\prime}\right.$ and H-5'), $5.89(1 \mathrm{H}, \mathrm{s}, \mathrm{H}-6), 6.05(1 \mathrm{H}, \mathrm{s}, \mathrm{H}-8), 5.56(1 \mathrm{H}, \mathrm{dd} J=6.1$ and $2.1 \mathrm{~Hz}$, $\mathrm{H}-2), 3.16\left(1 \mathrm{H}, \mathrm{m}, \mathrm{H}-3_{\mathrm{a}}\right), 2.80\left(1 \mathrm{H}, \mathrm{br} \mathrm{d} J=16.0 \mathrm{~Hz}, \mathrm{H}-3_{\mathrm{b}}\right) .{ }^{13} \mathrm{C}\left(\mathrm{DMSO}-d_{6}, 125 \mathrm{MHz}\right): \delta_{\mathrm{C}} 196.9(\mathrm{C}-4)$,

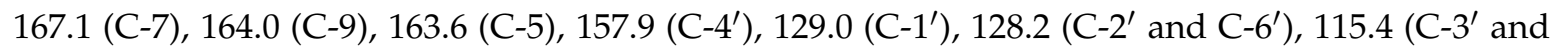
C-5') 102.2 (C-10), 96.2 (C-6), 95.4 (C-8), 79.1 (C-2), 42.8 (C-3). The data are in accordance with those published by Du et al. (2004) [13].

Compound 2 was obtained as yellow powder. ${ }^{1} \mathrm{H}\left(\mathrm{DMSO}-d_{6}, 500 \mathrm{MHz}\right): \delta_{\mathrm{H}} 6.92(2 \mathrm{H}, \mathrm{s}, \mathrm{H}-2$ and H-6). ${ }^{13} \mathrm{C}\left(\mathrm{DMSO}-d_{6}, 125 \mathrm{MHz}\right): \delta_{\mathrm{C}} 165.9$ (C-1'), 145.9 (C-3 and C-5), 139.2 (C-4), 119.3 (C-1), 109.2 (C-2 and C-6). The data are in accordance with those published by Santana et al. (2012) [14].

Other researchers have identified gallic acid in leaves and stem bark of S. terebinthifolius [14,15], but there are no reports on the presence of naringenin flavanone in this species. The presence of I30',II8-binaringenin in S. terebinthifolius was confirmed and allocated to the internal part of the fruit [16]. Some studies have identified only tetrahydrorobustaflavone [8] and tetrahydroamentoflavone [17] compounds in S. terebinthifolius, which are binaringenine linked at positions 6 and $5^{\prime}$, respectively, and I30,II8-binaringenin [18] and I3,II3-binaringenin [19] in fruits of Schinus molle have been reported. The present work is the first report on flavonoid naringenin and the activities attributed to it in this species.

\subsection{Total Phenolic Compounds, Total Flavonoid Content and Antioxidant Activity}

Natural compounds are responsible for the protective effect of cells against oxidative damage caused by Reactive Oxygen Species (ROS) [20]. Excess ROS in the body can cause a number of 
complications such as lipid peroxidation in cell membranes, aggression to proteins and enzymes and DNA damage, which can trigger pathological processes including cell aging, the onset of cancer, cardiovascular diseases, and other chronic diseases $[6,7,20]$. Antioxidants, which are responsible for neutralizing the effects of ROS, can be mainly found in compounds derived from secondary metabolites from plant sources, such as phenolic compounds $[10,21]$. Hence the need to determine the antioxidant activity and content of total flavonoids and phenolics in plants, since this is an important step for the identification of possible sources of bioactive molecules.

Table 1 shows the content of total phenolic compounds, flavonoids and the antioxidant activity of the G5 fraction of S. terebinthifolius fruits using the Folin-Ciocalteau, aluminum chloride colorimetric assay and DPPH free radical methods, respectively. The results showed a significant phenolic content (over $650 \mathrm{mg}$ Gallic Acid Equivalent (GAE)/g), a large amount of flavonoids (140.69 mg Rutin Equivalent (RE)/g), and high antioxidant activity (above 70\%) for Schinus terebinthifolius fruits.

Table 1. Total phenolic compounds, total flavonoid content, and antioxidant activity of G5 fraction from Schinus terebinthifolius Raddi fruit extract.

\begin{tabular}{cccccc}
\hline & $\begin{array}{c}\text { Total Phenolic } \\
\text { Compounds } \\
\text { (mg GAE } / \mathbf{g})\end{array}$ & $\begin{array}{c}\text { Total Flavonoid } \\
\text { Content } \\
\left(\mathbf{m g ~ R E}{ }^{* * / g}\right)\end{array}$ & \multicolumn{3}{c}{ Antioxidant Activity (\%) } \\
\hline & & & $\mathbf{0 . 0 1} \mathbf{~} \mathbf{g} / \mathbf{m L}$ & $\mathbf{0 . 0 1} \mathbf{~} \mathbf{~ g / m L}$ & $\mathbf{0 . 0 1} \mathbf{~ m g / m L}$ \\
\hline Fraction G5 & $659.21 \pm 6.05$ & $140.69 \pm 9.44$ & $77.5 \pm 2.57$ & $75.0 \pm 6.78$ & $69.2 \pm 6.47$ \\
Quercetin & $1214.71 \pm 9.51$ & $1009.27 \pm 7.85$ & $77.2 \pm 0.73$ & $74.1 \pm 3.82$ & $71.0 \pm 3.63$ \\
BHT $* * *$ & & & $76.4 \pm 1.98$ & $75.0 \pm 4.94$ & $66.3 \pm 4.20$ \\
\hline
\end{tabular}

Values are means of three determinations standard deviation. * GAE = Gallic Acid Equivalent, ** Rutin Equivalent, *** BHT = Butylated hydroxytoluene.

The content of total phenolics found in the Aroeira fruits used in the present study was significantly higher than that reported in the literature for the same species for fruit extract: $110 \mathrm{mg}$ GAE/g [21], leaf extract: $384.64 \mathrm{mg} \mathrm{GAE} / \mathrm{g}$ [22], extract from the stem: $309.03 \mathrm{mg} \mathrm{GAE} / \mathrm{g}$ [21], and extract from the bark: $207 \mathrm{mg} \mathrm{GAE} / \mathrm{g}$ [21]. A study proved that the maceration method was almost 20 times more effective than the soxhlet method, and the solvent used (methanol) was also the most effective to determine the content of total phenolics in Aroeira fruits [21].

Tabaldi et al. (2016) found a value lower than that of our work for total flavonoids in the methanolic extract from Aroeira leaves: $111.81 \mathrm{mg}$ of quercetin equivalent (QE)/g extract [23]. Fedel-Miyasato et al. (2014) studied the same type of extract and reported a much higher value: $460.20 \mathrm{mg} \mathrm{QE} / \mathrm{g}$ [24]. This value is higher than that found by Uliana et al. (2016) for ethanolic extract from leaves of S. terebinthifolius: $69.67 \mathrm{mg} \mathrm{QE} / \mathrm{g}$ of macerated extract and $243.09 \mathrm{mg} \mathrm{QE} / \mathrm{g}$ of extract obtained with the use of assisted ultrasound technique [20].

Generally, several assays have been frequently used to estimate antioxidant capacity in fruits and their products [25]. However, 2,2-diphenyl-1-picrylhydrazyl (DPPH) method measures the ability to scavenge free radicals. The test is simple, relatively rapid, reproducible, and does not require specialized equipment, and thus can be used for assessing antioxidant activity in foods and plant extracts [26].

Ethanolic extract from different parts of Aroeira obtained by maceration showed the following approximate antioxidant activities: fruits-60\%, stem-90\%, peels-70\%, and leaves-30\% [21]. The methanolic extract from Aroeira fruits showed antioxidant activity of $95.6 \%$ by the DPPH method in the work of Bernardes et al. (2014) [27]. El-Massry et al. (2009) evaluated the antioxidant activity of ethanolic extract, dichloromethane extract and essential oil from Aroeira leaves and observed that the ethanolic extract presented the highest antioxidant activity, with free radical sequestration above $80 \%$ [25]. 
Differences in the obtained values may be due to many factors. For example, climate conditions and fruit variety as well as processing methods (extraction, filtration, isolation), and storage conditions (air, temperature) can cause changes in the composition of phenols [8,28]. Furthermore, the antioxidant capacity of biomolecules is significantly influenced by the structure. The activity may be attributed to the enhanced stabilization of the radical state during electron transfer $[10,20]$. The present work is the first report on flavonoid naringenin and the activities attributed to it in this species.

\subsection{In Vivo Blood Pressure Assessment}

Phenolic compounds are the main compounds related to antioxidant activity, and the scavenging of free radicals caused by this activity may favor cardiovascular parameters in individuals. An intravenous infusion of the G5 fraction was administered in rats to investigate if this sample may cause changes in blood pressure. After the administration of the infusion of G5, all parameters analyzed were significantly reduced compared to the final pressure and the control (DMSO) in Wistar rats at 5\% probability (Figure 3). Comparison between pressure after G5 infusion and final pressure showed that the systolic pressure decreased by $128.3 \mathrm{mmHg}$, the median pressure decreased by $115.4 \mathrm{mmHg}$ and the diastolic pressure decreased by $100.3 \mathrm{mmHg}(p<0.05)$. Comparison between G5 pressure and the DMSO control showed that the systolic pressure was reduced by $51.72 \mathrm{mmHg}$, the median pressure decreased by $37.83 \mathrm{mmHg}$ and the diastolic pressure decreased by $26.35 \mathrm{mmHg}$ $(p<0.05)$.
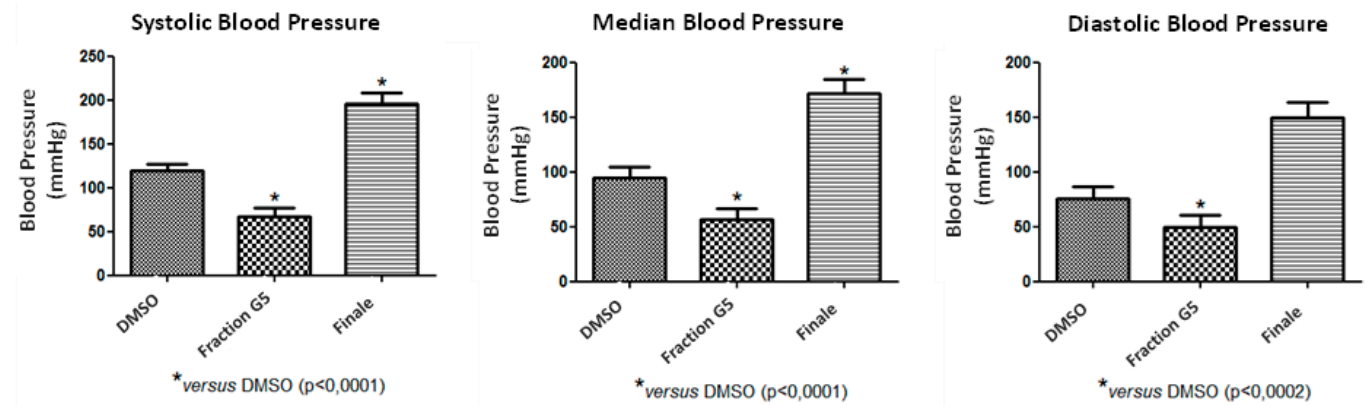

Figure 3. Effects of the G5 fraction ( $30 \mathrm{mg} / \mathrm{kg}$ ) from Schinus terebinthifolius Raddi fruit extract on the blood pressure of Wistar rats. Systolic blood pressure (SBP), median blood pressure (MBP), diastolic blood pressure (DBP). The values are expressed as mean \pm SEM from eight experiments. One-way ANOVA followed by Newman-Keuls test $\left({ }^{*} p<0.05\right.$ compared to control).

In this paper, it has been shown that G5 is a compound that induces blood pressure decrease in rats evaluated in vivo by intravenous administration. Hypertension is an important public health problem and is one of the most common cardiovascular diseases [29]. Phenolic compounds, which perform antioxidant activity, have already been associated with coronary vasodilator activity [9,29]. This stresses the relevance of developing new specific antihypertensive drugs with potential for clinical use.

The possible mechanisms by which phenolic compounds perform cardiovascular activity have led to studies on free radical sequestration, inhibition of lipid peroxidation, and enzymatic activities $[9,30]$. Phenols also inhibit platelet aggregation and the oxidation of LDL cholesterol and promote vasodilation, thus ensuring the integrity of blood vessels [9,31].

There are no reports in the literature on cardiovascular activity for any species of Schinus spp. However, for other species of the Anacardiaceae family, the following is described: aqueous extract of bark stem of Anacardium occidentale was administered intravenously in rabbits and significantly reduced arterial pressure and the contractile activity of the isolated heart of rat, thus presenting in vivo hypotensive activities and in vitro cardio-inhibitory activity [32]. Aqueous extract from the Harpephyllum caffrum stem significantly reduced systemic arterial pressures and heart rates in hypertensive rats after intravenous administration of the extract. The hypotensive effects are believed 
to be related to the presence of polyphenolic compounds and flavonoids in the plant [33]. Extracts from leaves of Sclerocarya birrea showed a significant antagonistic effect on calcium release due to the vasorelaxing effect observed in arterial vessels of rats, since calcium ions are responsible for the contraction of the smooth muscle [34].

In the present study, it was also observed that the administration of the G5 fraction significantly affected ( $p<0.0001)$ the motor incoordination of the mice (performance in rotarod) (Figure 4 ). As the time of permanence of G5 in the rotating bar was shorter than that of animals using diazepam, which is the positive control with activity on the central muscle relaxation, it is concluded that this sample has a more direct action on the central nervous system, with an effect on the peripheral musculature. If the time of permanence in the bar had been equal to that obtained with diazepam, the action would have been only on the peripheral plate.

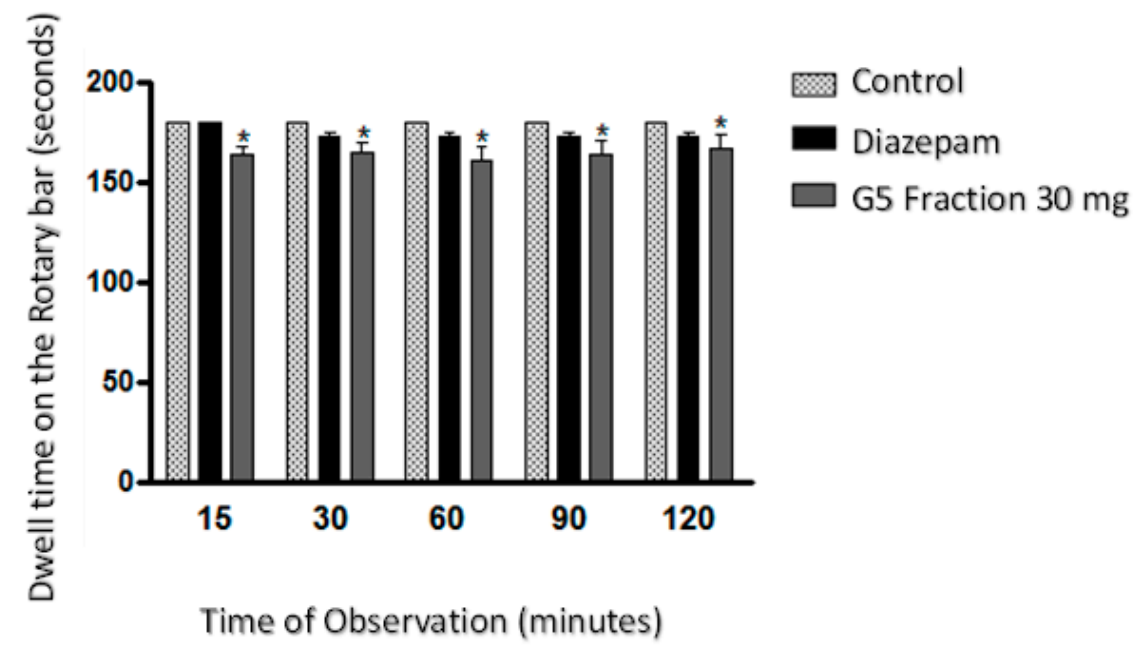

*versus Control and Diazepam $(p<0.0001)$

Figure 4. Effects of the G5 fraction ( $30 \mathrm{mg} / \mathrm{kg}$ ) Schinus terebinthifolius Raddi fruit extract on Swiss mice (Mus musculus) in the Rotarod test. The values are expressed as means \pm SEM of ten experiments. One-way ANOVA followed by Newman-Keuls test (* $p<0.05$ compared to the control).

Treatment with G5 produced hypolocomotion, increased immobility and muscular incoordination, with activity mainly observed on the central nervous system of the mice. These findings contradict previous studies reporting that the extract from the $S$. terebinthifolius stem bark alleviated the effects of rat motor incoordination caused by the administration of rotenone in the rotarod test [15], and that mangiferin isolated from the bark of Mangifera indica L. (Anacardiaceae) did not produce any significant effect on motor coordination in rotarod in rats indicating that the observed antinociception was not related to sedation or motor anomaly, but to the peripheral antinociceptive activity [35].

According to Seaman (2000), the locomotor impairment produced by G5 may be related to reduced energy levels and consequent changes in neural processing [36]. The brain is highly susceptible to free radical damage due to its high rate of oxygen utilization and the relatively low presence of antioxidant enzymes and free radical scavengers. There is growing interest in the establishment of therapeutic and dietary strategies to combat oxidative stress induced by damage mainly to the central nervous system [15]. Oxidative stress is a result of an imbalance between free radicals and may be ameliorated by the endogenous action of antioxidant defense systems [21]. Thus, the discovery of new natural sources rich in phenolic compounds and presenting antioxidant potential can prove the efficacy of the plants used in popular medicine, whose biological activities are scientifically proven. The present work is the first report on flavonoid naringenin and the activities attributed to it in this species. 


\section{Materials and Methods}

\subsection{General Experimental Procedures}

${ }^{1} \mathrm{H}-(500 \mathrm{MHz})$ and ${ }^{13} \mathrm{C}-(125 \mathrm{MHz}) \mathrm{NMR}$ data were obtained on a Bruker Advance II 9.4 T instrument (Centro de Ciências e Tecnologia, UENF) using DMSO- $d_{6}$ as solvent. Chromatographic purifications were carried out by using Sephadex LH-20 (25-100 $\mu \mathrm{m}$, Sigma-Aldrich, St. Louis, MO, USA). High Performance Liquid Chromatography analyses were performed using a Shimadzu Prominence HPLC system with two LC10AT pumps, a scanning ultraviolet SPD-M10A photodiode array detector and a Rheodyne $7725 \mathrm{i}$ injector. The reverse-phase column used was an RP-18 (5 $\mu \mathrm{m}$, 250 mm, 4.5 mm i.d., Macherey-Nagel, Bethlehem, PA, USA). Temperature: $32{ }^{\circ} \mathrm{C}$. Mobile phase: $\mathrm{A}=$ purified water adjusted to $\mathrm{pH} 3.2$ with phosphoric acid, $\mathrm{B}=$ acetonitrile was used as eluent. Flow elution rate was $1.0 \mathrm{~mL} / \mathrm{min} ; 20 \mu \mathrm{L}$ of the samples $(4 \mathrm{mg} / \mathrm{mL})$ were injected, detection: $254 \mathrm{~nm}$. Solvent composition during analysis: $0^{\prime}: 100 \% \mathrm{~A} ; 5^{\prime}: 70 \% \mathrm{~A} ; 10^{\prime}: 50 \% \mathrm{~A} ; 15^{\prime}: 30 \% \mathrm{~A} ; 20^{\prime}: 20 \% \mathrm{~A} ; 25^{\prime}: 10 \% \mathrm{~A}$; 30': 0\% A; 32': stop. The UV/VIS spectrophotometer (Epoch-BioTek—versão: Gen 5 1:10, Winooski, VT, USA) was used. The hemodynamic parameters were measured using the Bioamp equipment (Adinstrumentes, Australia), and Graph Labsoftware (version 7.0; AD Instruments). The automated Rota Rod instrument (EFF 411, Insight ${ }^{\circledR}$ ) was used.

\subsection{Chemicals}

Deuterated dimethyl sulfoxide (DMSO- $d_{6}$ purity $>99 \%$ ), Folin-Ciocalteu reagent, Butylated hydroxytoluene (BHT 99\% purity), 2,2-Diphenyl-2-picryl hydrazyl (DPPH purity $\geq 99 \%$ ), gallic acid and rutin, quercetin (purity of standards $\geq 99 \%$ ) were all purchased from Sigma-Aldrich. Merck acetonitrile (HPLC purity $\geq 99.9 \%$ ) was obtained from Merck. The anhydrous sodium carbonate $\left(\mathrm{Na}_{2} \mathrm{CO}_{3}\right)$ was obtained from Synth. Aluminum chloride hexahydrate $\left(\mathrm{AlCl}_{3} \cdot 6 \mathrm{H}_{2} \mathrm{O}\right)$ was purchased from VETEC. Isoflurane $100 \%$ and diazepam $(5 \mathrm{mg} / \mathrm{mL})$ were obtained from Cristália, heparin $5000 \mathrm{IU} / \mathrm{mL}$ from Blaú-Cristal Pharma laboratory, sodium chloride $(\mathrm{NaCl} 0.9 \%)$ was purchased from Sanobiol. The other chemical reagents were purchased from VETEC.

\subsection{Animals}

The tests were performed on male and female Wistar rats (Rattus norvegicus) weighing between 250 and $300 \mathrm{~g}$ and male Swiss mice (Mus musculus) weighing between 25 and $30 \mathrm{~g}$ from the Animal Experimentation Unit of the Universidade Estadual do Norte Fluminense (UEA-UENF), which were kept in an environment with controlled temperature, $19{ }^{\circ} \mathrm{C}$, humidity of 50 to $60 \%$, and light/dark cycle of $12 \mathrm{~h}$. Water and food were offered ad libitum. The present study was approved by the UENF Ethics Committee for Animal Use (CEUA), registered under protocol number 353. Each animal was used in only one experiment.

\subsection{Plant Material}

The fruits of Schinus terebinthifolius Raddi were collected in Campos dos Goytacazes, Rio de Janeiro State, Brazil (Latitude $21^{\circ} 44^{\prime} \mathrm{S}$ and $41^{\circ} 18^{\prime} \mathrm{W}$; Altitude $12 \mathrm{~m}$ above sea level) in April 2014. A voucher specimen was identified and deposited at the UENF herbarium under the code H5073.

\subsection{Extraction and Isolation}

The fruits of S. terebinthifolius ( $250 \mathrm{~g}$ ) were cleaned, washed, and subjected to methanol extraction $(10 \% w / v)$ by static maceration for 30 days. Every seven days, the solvent was filtered through a paper filter (QUANTY number 41), placed to evaporate in water bath at $35^{\circ} \mathrm{C}$ and protected from light [37] so as to obtain the crude extract $(71.7 \mathrm{~g})$. Then, the crude extract was partitioned with ethyl acetate resulting in two fractions: aqueous and organic. The organic fraction was rotary evaporated at $40{ }^{\circ} \mathrm{C}$. The fractionation of the organic fraction ( $38.7 \mathrm{~g}$ ) occurred in open Sephadex LH-20 Chromatographic 
Column using methanol as the eluent, which resulted in three fractions: G1 (7.6 g), G2 (19.4 g), and G3 (8.1 g). The G3 fraction was injected again into the Sephadex LH-20 column with methanol, and two more fractions were obtained: G4 (3.2 g) and G5 (4.4 g). The fraction G5 was the one used in the present work due to the profile shown in Thin Layer Chromatography (TLC) similar to flavonoids and phenolic compounds.

\subsection{Total Phenolic Compounds}

The total phenolic compounds were determined by the Folin-Ciocalteau method previously described by Singleton et al. (1999) with modifications, using gallic acid calibration curve concentrations from 0 to $500 \mu \mathrm{g} / \mathrm{mL}$ [38]. An aliquot of $0.1 \mathrm{~mL}$ of sample diluted in methanol $(1.0 \mathrm{mg} / \mathrm{mL})$ was added in $1.0 \mathrm{~mL}$ of methanol and $0.1 \mathrm{~mL}$ of the Folin-Ciocalteau reagent. The mixture was homogenized and received the addition of $1.0 \mathrm{~mL}$ of $\mathrm{Na}_{2} \mathrm{CO}_{3}(7 \%)$ after $5 \mathrm{~min}$. The reaction occurred for $90 \mathrm{~min}$, in the dark, at room temperature. The absorbance was read at $760 \mathrm{~nm}$ and the results were expressed in milligrams of gallic acid equivalents (mg GAE/g) per gram of sample.

\subsection{Total Flavonoid Content}

Total flavonoids were established by a colorimetric assay described by Woisky and Salatino (1998) with modifications [39]. An aliquot of $7.5 \mathrm{~mL}$ of sample $(0.1 \mathrm{mg} / \mathrm{mL}$ in methanol) was added to $0.5 \mathrm{~mL}$ of $\mathrm{AlCl}_{3}(5 \% \mathrm{w} / \mathrm{v})$ and then to $25 \mathrm{~mL}$ of methanol. Absorbance reading was performed at $425 \mathrm{~nm}$ after $30 \mathrm{~min}$ at rest. The flavonoid content was calculated using rutin calibration curve concentrations from 0 to $100 \mathrm{mg} / \mathrm{mL}$. The results were expressed in milligrams of rutin equivalents per gram of sample (RE/g).

\subsection{Antioxidant Activity}

The antioxidant activity was determined by the stable free radical DPPH method (2,2-diphenyl-1-picryl-hydrazyl) [26]. The samples were prepared in methanol at 2,0.2 and 0.02 $\mathrm{mg} / \mathrm{mL}$. Samples $(0.5 \mathrm{~mL})$ were added to $0.5 \mathrm{~mL}$ methanolic solution of DPPH (4\%) to final concentrations of $1,0.1$ and $0.01 \mathrm{mg} / \mathrm{mL}$. The reaction was incubated in darkness, for $60 \mathrm{~min}$ at $25^{\circ} \mathrm{C}$. The absorbance values were measured at $515 \mathrm{~nm}$. The radical scavenging activity (\% inhibition) was expressed as percentage of scavenged DPPH and calculated according to the following equation: \% of Inhibition = [(ADPPH - Asample) $/ \mathrm{ADPPH}] \times 100$, where ADPPH is the absorbance of DPPH solution (negative control) and Asample is the absorbance of the sample in the presence of DPPH. BHT and quercetin were used as positive controls.

\subsection{In Vivo Blood Pressure Assessment}

Wistar rats were anesthetized by inhalation with isoflurane and contained for catheter insertion in the left carotid artery, through which the following parameters analyzed were measured: systolic, median, and diastolic blood pressure. The cannula was heparinized with a sodium heparin solution and $0.9 \%$ sodium chloride in order to avoid blood clotting. Another catheter was inserted into the jugular vein for intravenous infusion of the G5 fraction at a dose of $30 \mathrm{mg} / \mathrm{kg}$ diluted in DMSO with a volume of $0.1 \mathrm{~mL}$ per animal. Prior to the tests, DMSO alone was infused at the same dose to serve as a control so as to eliminate the hypotensive effects of DMSO on the results.

\subsection{Rotarod Test}

The Swiss mice (Mus muscullus) were previously tested on the rotating bar. Those that fell two or more times in three-minute period were discarded. After the selection of the animals, the G5 fraction and the diazepam positive control were administered intraperitoneally, $0.1 \mathrm{~mL}$ volume and $300 \mathrm{mg} / \mathrm{mL}$ concentration in DMSO. 
Each individual was placed with all four legs on a rotating bar of $8 \mathrm{~cm}$ diameter, $20 \mathrm{~cm}$ from the bottom of the equipment, already in motion $(20 \mathrm{rpm})$. The time they could balance before falling was measured. The mice were observed at the times of 15, 30, 60, 90, and $120 \mathrm{~min}$ after sample administration, and remained on the rotating bar for three minutes. At the fall, the chronometer used to verify the time of equilibrium would stop automatically, the animals returned to their respective bars, and the chronometer would be reactivated, so that the total falls would be counted after the three minutes, while a general timer measured the total time of the test (120 $\mathrm{min})$.

\subsection{Statistical Analysis}

All experiments were performed in triplicates, and the results were expressed as mean \pm standard deviation (SD). The results obtained were tabulated by the LabChart 7 program, and statistically analyzed through the GraphPad Prisma 5. The analysis of variance (ANOVA) was defined, followed by the Newman-Keuls and Bonferroni mean test, with reliability index of $95 \%$.

\section{Conclusions}

This study provides evidence for the pharmacological antihypertensive and antioxidant potential of Schinus terebinthifolius Raddi fruit extract. Phytochemical investigations identified two major compounds of the G5 fraction from methanolic extract: naringenin (first report in this species) and gallic acid, which were analyzed for the first time by inducing blood pressure decrease evaluated in vivo. Phenolic compounds present in S. terebinthifolius were identified as a promising natural source to combat cardiovascular and related diseases.

Supplementary Materials: ${ }^{1} \mathrm{H}$ - ${ }^{13} \mathrm{C}$ - and ${ }^{13} \mathrm{C}-\mathrm{DEPTQ}$ NMR spectra, COSY, HSQC, and HMBC spectra correlations, and structures of compound $\mathbf{1}$ and $\mathbf{2}$ assembled with the aid of COSY correlations are available as Supplementary Materials available online.

Acknowledgments: The authors are grateful to Fundação Carlos Chagas de Amparo à Pesquisa do Estado do Rio de Janeiro (FAPERJ) by grant and for project financial support; to Conselho Nacional de Desenvolvimento Científico e Tecnológico (CNPq), to Coordenação de Aperfeiçoamento de Pessoa de Nível Superior (CAPES), and UENF for research fellowships and the financial support.

Author Contributions: L.d.L.G. and D.B.d.O. conceived and designed the experiments; A.R.d.C.J., R.B.-F., and I.J.C.V. performed the experiments on NMR analysis; L.d.L.G. and S.M.d.F.P. performed the analysis on HPLC; L.d.L.G. and M.B.d.S.A. performed the phenolic compounds, flavonoid content and DPPH tests; L.d.L.G., F.A., G.d.S.V., and C.X.M. performed the antihypertensive analysis; L.d.L.G., L.L.d.C., D.B.d.O., D.S.d.A.C., and S.d.P.F. wrote the article.

Conflicts of Interest: The authors declare no conflict of interest.

\section{References}

1. Bae, J.W.; Kim, D.H.; Lee, W.W.; Kim, H.Y.; Son, C.G. Characterizing the human equivalent dose of herbal medicines in animal toxicity studies. J. Ethnopharmacol. 2015, 162, 1-6. [CrossRef] [PubMed]

2. Holtmann, G.; Talley, N.J. Herbal medicines for the treatment of functional and inflammatorybowel disorders. Clin. Gastroenterol. Hepatol. 2015, 13, 422-432. [CrossRef] [PubMed]

3. Farzaneh, V.; Carvalho, I.S. A review of the health benefit potentials of herbal plant infusions and their mechanism of actions. Ind. Crops Prod. 2015, 65, 247-258. [CrossRef]

4. Corrêa, M.P. Dicionário de Plantas Úteis do Brasil e das Exóticas Cultivadas; Ministério da Agricultura, Instituto Brasileiro de Desenvolvimento Florestal: Rio de Janeiro, RJ, Brazil, 1984; Volume 6, pp. 170-171.

5. DiCiaula, M.C.; Lopes, G.C.; Scarminio, I.S.; De Mello, J.C.P. Optimization of solvent mixtures for extraction from bark of Schinus terebinthifolius by a statistical mixture-design technique and development of a UV-VIS spectrophotometric method for analysis of total polyphenols in the extract. Quim. Nova 2014, 37, 158-163. [CrossRef]

6. Shahidi, F.; Ambigaipalan, P. Novel Functional Food Ingredients from Marine Sources ScienceDirect Novel functional food ingredients from marine sources. Curr. Opin. Food Sci. 2015, 2, 123-129. [CrossRef] 
7. Haytowitz, D.B.; Bhagwat, S.; Holden, J.M. Sources of variability in the flavonoid content of foods. Procedia Food Sci. 2013, 2, 46-51. [CrossRef]

8. Kassem, M.E.S.; El-Desoky, S.K.; Sharaf, M. Biphenyl esters and biflavonoids from the fruits of Schinus terebinthifolius. Chem. Nat. Compd. 2004, 40, 447-450. [CrossRef]

9. Penso, J.; Cordeiro, K.C.F.A.; Da Cunha, C.R.M.; Da Silva Castro, P.F.; Martins, D.R.; Lião, L.M.; Rocha, M.L.; De Oliveira, V. Vasorelaxant activity of 7- $\beta$-O-glycosides biosynthesized from flavonoids. Eur. J. Pharmacol. 2014, 733, 75-80. [CrossRef] [PubMed]

10. Ali, S.S.; Kasoju, N.; Luthra, A.; Singh, A.; Sharanabasava, H.; Sahu, A.; Bora, U. Indian medicinal herbs as sources of antioxidants. Food Res. Int. 2008, 41, 1-15. [CrossRef]

11. Kanaze, F.I.; Kokkalou, E.; Georgarakis, M.; Niopas, I. A validated solid-phase extraction HPLC method for the simultaneous determination of the citrus flavanone aglycones hesperetin and naringenin in urine. J. Pharm. Biomed. Anal. 2004, 36, 175-181. [CrossRef] [PubMed]

12. Song, R.; Cheng, Y.; Tian, Y.; Zhang, Z.J. A validated solid-phase extraction HPLC method for the simultaneous determination of gallic acid, catechin and epicatechin in rhubarb decoction. Chin. J. Nat. Med. 2012, 10, 275-278. [CrossRef]

13. Du, Q.Z.; Jerz, G.; Winterhalter, P. Preparation of three flavonoids from the bark of Salix alba by high-speed countercurrent chromatographic separation. J. Liq. Chromatogr. Relat. Technol. 2004, 27, 3257-3264. [CrossRef]

14. Santana, J.S.; Sartorelli, P.; Lago, J.H.G.; Matsuo, A.L. Isolamento e avaliação do potencial citotóxico de derivados fenólicos de Schinus terebinthifolius raddi (anacardiaceae). Quim. Nova 2012, 35, 2245-2248. [CrossRef]

15. Sereniki, A.; Linard-Medeiros, C.F.B.; Silva, S.N.; Silva, J.B.R.; Peixoto Sobrinho, T.J.S.; da Silva, J.R.; Alvesa, L.D.S.; Smailic, S.S.; Wanderley, A.G.; Lafayette, S.S.L. Schinus terebinthifolius administration prevented behavioral and biochemical alterations in a rotenone model of Parkinson's disease. Braz. J. Pharmacogn. 2016, 26, 240-245. [CrossRef]

16. Feuereisen, M.M.; Gamero Barraza, M.; Zimmermann, B.F.; Schieber, A.; Schulze-Kaysers, N. Pressurized liquid extraction of anthocyanins and biflavonoids from Schinus terebinthifolius Raddi: A multivariate optimization. Food Chem. 2017, 214, 564-571. [CrossRef] [PubMed]

17. Skopp, G.; Schwenker, G. Biflavonoids from Schinus terebinthifolius Raddi (Anacardiaceae). Z. Naturforsch. B 1986, 41, 1479-1482. [CrossRef]

18. Ono, M.; Yamashita, M.; Mori, K.; Masuoka, C.; Eto, M.; Kinjo, J.; Ikeda, T.; Yoshimitsu, H.; Nohara, T. Sesquiterpenoids, triterpenoids, and flavonoids from the fruits of Schinus molle. Food Sci. Technol. Res. 2008, 14, 499-508. [CrossRef]

19. Yueqin, Z.; Recio, M.C.; Máñez, S.; Giner, R.M.; Cerdá-Nicolás, M.; Ríos, J.L. Isolation of two triterpenoids and a biflavanone with anti-inflammatory activity from Schinus molle fruits. Planta Med. 2003, 69, 893-898. [PubMed]

20. Uliana, M.P.; Fronza, M.; da Silva, A.G.; Vargas, T.S.; de Andrade, T.U.; Scherer, R. Composition and biological activity of Brazilian rose pepper (Schinus terebinthifolius Raddi) leaves. Ind. Crops Prod. 2016, 83, 235-240. [CrossRef]

21. Ribeiro, P.; Fernandez, L.; Loureiro, M.; Simões, R.; de Castro, R.; D'Sousa' Costa, C. Phytochemical screening, antioxidant and antibacterial activities of extracts prepared from different tissues of Schinus terebinthifolius Raddi that occurs in the coast of Bahia, Brazil. Pharmacogn. Mag. 2015, 11, 607. [CrossRef] [PubMed]

22. Bulla, M.K.; Hernandes, L.; Baesso, M.L.; Nogueira, A.C.; Bento, A.C.; Bortoluzzi, B.B.; Serra, L.Z.; Cortez, D.A.G. Evaluation of photoprotective potential and percutaneous penetration by photoacoustic spectroscopy of the Schinus terebinthifolius Raddi extract. Photochem. Photobiol. 2015, 91, 558-566. [CrossRef] [PubMed]

23. Tabaldi, L.A.; Vieira, M.C.; Zárate, N.A.H.; Formagio, A.S.N.; Pilecco, M.; Silva, L.R.; Santos, K.P.; Santos, L.A.C.; Cardoso, C.A.L. Biomass yield and flavonoid and phenol content of Schinus terebinthifolius cultivated in single or double row with poultry litter. Ciênc. Florest. 2016, 26, 787-796. [CrossRef]

24. Fedel-Miyasato, L.E.S.; Kassuya, C.A.L.; Auharek, S.A.; Formagio, A.S.N.; Cardoso, C.A.L.; Mauro, M.O.; Cunha-Laura, A.L.; Monreal, A.C.D.; Vieira, M.C.; Oliveira, R.J. Evaluation of anti-inflammatory, immunomodulatory, chemopreventive and wound healing potentials from Schinus terebinthifolius methanolic extract. Braz. J. Pharmacogn. 2014, 24, 565-575. [CrossRef] 
25. El-Massry, K.F.; El-Ghorab, A.H.; Shaaban, H.A.; Shibamoto, T. Chemical compositions and antioxidant/antimicrobial activities of various samples prepared from Schinus terebinthifolius leaves cultivated in Egypt. J. Agric. Food Chem. 2009, 57, 5265-5270. [CrossRef] [PubMed]

26. Brand-Williams, W.; Cuvelier, M.E.; Berset, C. Use of a free radical method to evaluate antioxidant activity. LWT Food Sci. Technol. 1995, 28, 25-30. [CrossRef]

27. Bernardes, N.R.; Heggdorne-Araújo, M.; Borges, I.F.J.C.; Almeida, F.M.; Amaral, E.P.; Lasunskaia, E.B.; Muzitano, M.F.; Oliveira, D.B. Nitric oxide production, inhibitory, antioxidant and antimycobacterial activities of the fruits extract and flavonoid content of Schinus terebinthifolius. Braz. J. Pharmacogn. 2014, 24, 644-650. [CrossRef]

28. Šamec, D.; Piljac-Žegarac, J. Postharvest stability of antioxidant compounds in hawthorn and cornelian cherries at room and refrigerator temperatures-Comparison with blackberries, white and red grapes. Sci. Hortic. (Amst.) 2011, 131, 15-21. [CrossRef]

29. Torres-Piedra, M.; Figueroa, M.; Hernández-Abreu, O.; Ibarra-Barajas, M.; Navarrete-Vázquez, G.; Estrada-Soto, S. Vasorelaxant effect of flavonoids through calmodulin inhibition: Ex vivo, in vitro, and in silico approaches. Bioorg. Med. Chem. 2011, 19, 542-546. [CrossRef] [PubMed]

30. Lobo De Andrade, D.M.; Reis, C.D.F.; Castro, P.F.D.S.; Borges, L.L.; Amaral, N.O.; Torres, I.M.S.; Rezende, S.G.; Gil, E.D.S.; Cardoso Da Conceicao, E.; Pedrino, G.R.; et al. Vasorelaxant and hypotensive effects of jaboticaba fruit (Myrciaria cauliflora) extract in rats. Evid. Based Complement. Altern. Med. 2015, 2015, 696135. [CrossRef] [PubMed]

31. Wang, T.; Li, Q.; Bi, K. Bioactive flavonoids in medicinal plants: Structure, activity and biological fate. Asian J. Pharm. Sci. 2017, in press. [CrossRef]

32. Tchikaya, F.O.; Bantsielé, G.B.; Kouakou-Siransy, G.; Datté, J.Y.; Yapo, P.A.; Zirihi, N.G.; Offoumou, M.A. Anacardium occidentale Linn. (Anacardiaceae) stem bark extract induces hypotensive and cardio-inhibitory effects in experimental animal models. Afr. J. Tradit. Complement. Altern. Med. 2011, 8, 452-461. [CrossRef] [PubMed]

33. Ojewole, J.A. Hypoglycaemic and hypotensive effects of Harpephyllum caffrum Bernh ex CF Krauss (Anacardiaceae) stem-Bark aqueous extract in rats. Cardiovasc. J. S. Afr. 2006, 17, 67-72. [PubMed]

34. Belemtougri, R.G.; Constantin, B.; Cognard, C.; Raymond, G.; Sawadogo, L. Effects of Sclerocarya birrea (A. rich) hochst (Anacardiaceae) leaf extracts on calcium signalling in cultured rat skeletal muscle cells. J. Ethnopharmacol. 2001, 76, 247-252. [CrossRef]

35. Lopes, S.C.; Da Silva, A.V.L.; Arruda, B.R.; Morais, T.C.; Rios, J.B.; Trevisan, M.T.S.; Rao, V.S.; Santos, F.A. Peripheral antinociceptive action of mangiferin in mouse models of experimental pain: Role of endogenous opioids, KATP-channels and adenosine. Pharmacol. Biochem. Behav. 2013, 110, 19-26. [CrossRef] [PubMed]

36. Seaman, R.L. Effects of acute systemic 3-nitropropionic acid administration on rat activity and acoustic startle. Neurosci. Lett. 2000, 280, 183-186. [CrossRef]

37. Association of Official Analysis Chemists (AOAC). Official Methods of Analysis of the Association of Official Analysis Chemists; AOAC: Gaithersburg, MD, USA, 1995; p. 957.

38. Singleton, V.L.; Orthofer, R.; Lamuela-Raventós, R.M. Analysis of total phenols and other oxidation substrates and antioxidants by means of folin-ciocalteu reagent. Methods Enziymol. 1999, 299, 152-178.

39. Woisky, R.G.; Salatino, A. Analysis of propolis: Some parameters and procedures for chemical quality control. J. Apic. Res. 1998, 37, 99-105. [CrossRef]

Sample Availability: Samples of the compounds $\mathbf{1}$ and $\mathbf{2}$ are available from the authors. 